\title{
The Consequences of Liberal Modernity: Explaining and Resisting Neoliberalism Through Alasdair Macintyre
}

John Gregson

School of Social Sciences

Leeds Beckett University

City Campus, CL905, Portland Way, Leeds LS1 3HE.

01138125790

J.Gregson@leedsbeckett.ac.uk

\section{Abstract}

Neoliberalism is, in various ways, radically new. It is nevertheless constructed from the conditions of liberal modernity, the inadequacies of which are crucial to neoliberal success. Liberalism in practice restricts moral agency through an impoverished, structurally-reinforced conception of practical reasoning, as Alasdair Maclntyre argues, and this is important to understanding neoliberal durability. This paper argues that a bureaucratic culture that fails to evaluate or critically question the ends it pursues is both symptomatic of liberal inadequacies and a key factor in neoliberal success. Beyond its purely explanatory power, there is a political relevance to MacIntyre's Aristotelian-inspired politics of local community. It is from those practices and communal movements that embody alternative conceptions of the good, that those interested in resisting neoliberalism can learn how it becomes possible to successfully challenge aspects of the contemporary social order.

Keywords: MacIntyre; Neoliberalism; Liberal Modernity; Aristotelianism; Bureaucratic Rationality; Social Practices.

\section{Author Bio:}

John Gregson is a Senior Lecturer in Criminology at Leeds Beckett University. His research interests broadly intersect around criminology, politics and philosophy. He is the author of Marxism, Ethics and Politics: The Work of Alasdair Maclntyre (London: Palgrave MacMillan).

\section{Acknowledgements:}

Thanks to Jason Hannan and Karl Spracklen for their comments on earlier drafts of this paper. I would also like to thank two anonymous reviewers for their constructive comments that helped to strengthen this paper, together with the extensive editorial guidance from Andrew Schaap. 


\section{The Consequences of Liberal Modernity: Explaining and Resisting Neoliberalism Through Macintyre}

How are we to account for the success of Neoliberalism? The answer to this question has been formulated from a range of perspectives, the most influential of which draw from the resources of Foucauldian Governmentality and Marxism. Whilst Marxism broadly identifies neoliberalism as a successful economic and political project aimed at restoring class power, neoliberalism-asgovernmentality points to the crucial processes of subjectification that create a willing subject complicit in neoliberalism's success. Despite the insights afforded by these analyses, they offer an incomplete explanation of neoliberal success, insofar as they neglect how liberal modernity itself constructs the structural foundations and peculiarly vulnerable nature of the subject that are conducive to neoliberalism.

Accordingly, I turn to the resources provided by Alasdair MacIntyre's critique of liberal modernity. Despite having little to say specifically about Neoliberalism, Maclntyre is important to understanding how neoliberalism is able to flourish at least partially because of the broader failures of liberal practical reasoning that are embodied in modernity's social structures. The moral barrenness of liberal modernity is uniquely fertile ground for the requirements of neoliberalism. Indeed, a moral critique of neoliberalism is necessarily excluded from Foucauldian perspectives and limited from within the resources of Marxism, yet is crucial to understanding and resisting neoliberalism.

If neoliberalism has proven so durable, another question remains as to how it might be challenged. It has been argued that neoliberalism is successful not only at state level, but also in the way it locally embeds into the values and practices of individuals and communities. I suggest this provides a significant point of contact with Maclntyre's politics of local community which might foster resistance to neoliberalism from within social practices. Against the charges of political irrelevance, I argue for the significance of MacIntyre's politics, through which practitioners might challenge the economic rationality that neoliberalism embodies and the dehumanising effects of its policies.

Beginning with an overview of key theoretical interpretations of neoliberalism, the paper places neoliberalism within the context of a broader MacIntyrean critique of liberal modernity. I show how neoliberalism might be further understood through its relationship to liberalism in both theory and practice. Furthermore, if Maclntyre's Aristotelian framework can be used to highlight key inadequacies within variants of liberalism, it also provides a framework for political resistance to neoliberalism, which is the focus of latter sections. Arguably borne out in contemporary models of practice, Revolutionary Aristotelianism (Knight 2007) can both interpret and learn from such resistance movements as to how the goods of community can and do flourish. Black Lives Matters is one such movement from which those interested in understanding the nature and form of resistance in the contemporary world can learn.

\section{Historicizing Neoliberalism}

Wendy Larner (2000) is amongst a number of theorists who have identified three ways that neoliberalism can be understood - as policy, ideology, and governmentality. Straddling the policy and ideology approaches are Marxist or neo-Marxist explanations. These characterise neoliberalism as a stage of capitalism, a ruling-class strategy or a tool of restorative class-power (Davidson, 2013; Dumenil and Levy, 2005; Harvey, 2007). Marxist approaches incorporate the same economic 
framework as policy approaches (Venugopal, 2015), whilst maintaining a belief in the integral role of ideology to neoliberalism. Ideology explanations go beyond economics and politics into wider social life where neoliberalism is framed as a moral project of individualising ethics that rejects any conception of the common good (Olsen, 2008; Giroux, 2011). Accordingly, society itself views any attempt to tamper with market efficiency as 'morally suspect' (Frodeman et al, 2012, p. 313), and central to neoliberalism is the marketisation of previously un-economized aspects of social life.

Foucault's Birth of Biopolitics lectures are the starting point for the governmentality approach. This is perhaps the boldest framework for understanding neoliberalism, not least because it displaces the state from its more traditional place at the centre of social order. The state therefore matters less than the broader strategies of government into which it is incorporated (Hindess, 1997, p. 103). Foucault characterises the state as 'the mobile effect of a regime of multiple governmentalities' (Foucault, 2008, p. 77), as the 'correlative' of a 'particular way of governing (Foucault, 2008, p. 6). Neoliberalism has numerous sites of governmentality that together form a rationality that 'employs unprecedented techniques of power over conduct and subjectivities' (Dean, 2014, p. 88). The governmentality understanding shares with ideology approaches the assertion that neoliberalism involves the 'generalization of the economic form of the market' (Foucault, 2008, p. 243). Nevertheless, it is more pervasive as the binding logic of now-multiple sites of governmentality extends to creating a new rationality embodied in the atomistic behavior of 'homo œconomicus' (Foucault, 2008, p. 282).

These approaches suggest neoliberalism impacts the subject through denying critical resources to develop oppositional thinking, or through a Foucauldian transformation of the subject, or both. Neoliberalism develops a new internal rationality through the 'strategic programming of individuals' activity' (Foucault, 2008, p. 223). This creates willing participants conducive to pushing through neoliberal policy, of which higher education is a compelling example. The 'new type of teacher and head teacher', formed within the logic of competition and necessary to actualize such changes at an institutional level, is an example of Foucault's Homo Economicus (Ball and Olmedo, 2013, p. 88; Foucault 2008). Managerialism drives this agenda within a neoliberal environment characterised as 'an input-output system which can be reduced to an economic production function' (Olssen and Peters, 2005, p. 324). A significant shift from liberal to neoliberal governmentality involves the replacement of 'delegated authority' underpinned by 'relations of trust', with hierarchical management structures within higher education organizations (Olssen and Peters, 2005, p. 324). This places not only greater responsibility on the neoliberal manager but also gives them greater power in an economised education sector, enabling more effective suppression of criticality and resistance through the prioritisation of efficiency (Heath \& Burden, 2013; Preston and Aslett, 2014; Beckmann et al, 2009; Giroux, 2011). Ideology and governmentality approaches suggest neoliberalism's effectiveness is such that it becomes an almost intuitive logic - common sense. These processes flourish through an economic rationality that supresses the possibility of putting the market-driven ends neoliberalism pursues into question. Rather than neoliberalism being 'out there', it is now 'in here - in the head, the heart and the soul' (Ball, 2016, p. 1047).

The concept of resilience is important here, whether in the broader meaning of an ultimate acceptance that the world cannot be changed (Mavelli, 2017, p. 495), or a more specific understanding associated with governmentality. Both view neoliberalism as continuing to flourish despite its disastrous economic and social consequences - a 'zombie neoliberalism' capable of re- 
animating and preserving itself (Peck, 2010). From the Foucauldian perspective, the consequences of economic turmoil might not, contra Marxism, create resistance to neoliberalism but further its success. Resilience frames crises as constitutive of neoliberalism, furthering rather than challenging its hegemony through remoulding individuals to prepare for the inevitability of crises (Dean, 2014; Walker \& Cooper, 2011). The systemic failure to mitigate against crises are consequently reimagined as failures at an individual level.

Much of this literature accentuates neoliberalism's discontinuity with 'pre-neoliberal' modernity. Critics focus on Neoliberalism's specificity. Neoliberalism's restoration of class power is conceived as a 'new social order', whilst its governmental rationality is 'unprecedented' in its power over conduct and subjectivities ((Dumenil and Levy, 2005, p. 9; Dean, 2014, p. 88). Neoliberalism involves a radical transformation of the state (Harvey, 2007), placing its faith in the market to such an extent that market-thinking becomes so pervasive it is no longer noticed (Frodeman et al, 2012). Accordingly, a significant part of what is 'new' about neoliberalism is its seeming ability to transform both social reality and its inhabitants. Yet a MacIntyrean analysis implies the foundations for this success were laid through a historically-developed process that began with the liberal enlightenment. Through Maclntyre's analysis, we can see how neoliberalism flourishes due to an inadequate conception of liberal practical reasoning embodied in social structures. This suggests neoliberalism can be partially understood as the current manifestation of the standpoint of civil society (Maclntyre, 1994), the culmination of a deep-rooted liberal project of individualising ethics and social life.

Maclntyre's analysis suggests neoliberalism's success partially stems from the institutionalised failures of the liberal Enlightenment; his critique of modernity is rooted in a critique of the theory and practice of liberalism itself (Maclntyre, 1994; 1995; 2007). Theoretically, this is a critique of Kantian and Utilitarian approaches to morality; practically, the embedding of those frameworks in social life and their correspondence with capitalism. Maclntyre characterises Kant as the supreme being of the Enlightenment because his understanding of morality provides the dominant, institutionalised moral framework of our age (Maclntyre, 1991; 2007). Maclntyre's key point here is not that Kant's was a rationality of manipulation, indeed quite the opposite is true of Kant. Rather, it is that the Kantian inability to ultimately provide any objective justification for morality meant that any claim to objectivity - in practice - was itself rooted in manipulation and this became embodied in the protagonists of the liberal social order. An important part of Maclntyre's position is that such inadequate moral frameworks become institutionally and socially embodied, fostering manipulative social relations and a form of inadequate practical reasoning such as that seen in the neoliberal manager. Maclntyre agrees with Nietzsche that modern utility or rights-based frameworks are moral fictions in that they claim objectivity yet actually function as expressions of personal preference. It is these inadequate moral frameworks that dominate modernity, and which are simultaneously 'inadequate socially-embodied modes of practice' (Maclntyre, 1995, p. xxvii). The manipulative social relations of capitalism - intensified by neoliberal processes - are reflective of a historicallydeveloped, socially-embodied mode of practice, characterised by the central, liberal conception of the human good as an individualised good (MacIntyre, 1999, p. 220).

\section{Practical Rationalities and Social Structures}

Maclntyre's contribution to contemporary perspectives on Neoliberalism here is two-fold. Firstly, if neoliberalism is defined by the extension of the model of Homo Economicus beyond economics 
(Foucault, 2008), his analysis locates neoliberal economic rationality within the broader deficiencies of liberal practical rationality. Different forms of practical rationality presuppose different ways of understanding and each must be institutionalised if its norms are to be interpretive and actionguiding (MacIntyre, 1987, p. 127). A MacIntyrean understanding frames bureaucratic rationality, typical of the neoliberal environment, as an extension of a deficient but nevertheless dominant, institutionalised moral tradition. Whilst Governmentality identifies a more 'complex and nuanced' form of power that moulds public and private behaviour (Hindess, 1997, p. 131), this can usefully be understood through the lens of traditions of rationality, the institutionalisation of which shape the moral resources available to agents to challenge such power.

Secondly, if rationality is historical, and forms of rationality are tied to specific institutionalised social orders (Maclntyre, 1987), it is important to examine the nature of such institutions. Maclntyre provides an understanding of those structural conditions through which neoliberalism successfully extends the model of Homo Economicus. He conceives of social structures as seriously threatening the possibility of developing moral agency (Maclntyre, 1999a. p. 189), the possession of which is necessary to question the social order itself. This critical analysis of liberal modernity - rather than neoliberalism specifically - goes some way to answering the question as to what accounts for neoliberalism's success. By developing this historical and sociological account of liberal modernity, it allows Macintyre to argue that a rival form of practical rationality can be embodied within social practices, providing a moral and political alternative to neoliberalism that I will argue is missing from Foucauldian or Marxist analyses.

Maclntyre's approach to philosophy is historical and sociological. He argues that the structure of rational action differs widely between time and place - contrasting understandings of practical rationality are tied to specific social orders. Social orders resemble practices in that there are norms of rationality governing them just as there are norms governing other practices. Practical rationality directs action and individuals evaluate their rationality against the norms of their social order (Maclntyre, 1987, pp. 120-122). Two polarised understandings of practical rationality are the Aristotelian and modern liberal versions. Aristotelian practical rationality is achievable internally within practices directed towards certain goods. It is the role of political community to ensure that practical rationality can flourish beyond the confines of a practice, where goods are integrated into the lives of both individuals and communities (Maclntyre, 1987, p. 123).

A key failure of Liberal practical reasoning is that it conceptualises wants and desires free from any 'essential precedent process or set of occurrences' (Maclntyre, 1987, p. 129), as if detached from any conception of good or goods. Liberal practical rationality is judged only on the success or failure in getting individualised, essentially unquestioned, preferences implemented. It is only individuals in specific social roles who are the bearers of rationality, yet Maclntyre views the individual as a social role, a piece of 'social fabrication' created to abstract the individual from their social circumstances (Maclntyre, 1987, pp. 129-130). Both forms of rationality emerge from history and are bound by the same traditional-cultural constitutive elements of any other practices, allowing Maclntyre to argue that the 'tradition-eschewing' standpoint of liberal individualism is a 'false myth' (Lutz, 2004, p. 46). Traditions are 'bearers of reason' and partially constituted by historically-developed arguments as to the meaning of that tradition (Maclntyre, 1977a, p. 461). Significantly, if rationality itself is a practice then it can be evaluated and improved just like other practices (Lutz, 2004), giving a normative dimension to the Maclntyrean perspective which is both a critique of (neo)liberal practical rationality 
and an adherence to a superior, Aristotelian tradition of practical rationality. Aristotelian practical rationality encompasses the rational, participatory evaluation of both ends and means, whereas modern instrumental or bureaucratic rationality matches means to predetermined ends without questioning those ends, meaning the 'logical structure' of such 'superior rationality' is teleological (Knight, 2007, p. 165).

Maclntyre's analysis of rival conceptions of practical rationality is particularly pertinent when applied to the previously highlighted context of higher education. Bureaucratic rationality frames the neoliberal environment and consequently the role of the manager becomes ever more significant. The detachment of ends -such as the market-driven ends of neoliberalism - from any precedent inquiry into the nature of those ends is essential to what qualifies as success in the neoliberal environment. Accordingly, neoliberalism makes a double rejection of Aristotelian rationality - the manager possesses no means to rationally evaluate ends and, in any case, does not even recognise that ends themselves are subject to rational evaluation (Beabout, 2013). This characterises a higher education system that increasingly justifies funding in terms of - essentially unquestioned outcomes unconnected to any notion of the public or common good (Heath and Burden, 2013; Preston and Aslett, 2014; Beckman et al, 2014). Neoliberalism subverts us to its own truths and ends (Ball \& Olmedo 2013), which are themselves increasingly subsumed to market logic. In this situation, bureaucratic rationality becomes ever more important to pushing through a neoliberal agenda further removed from any conception of the common good (Giroux, 2011). This allows neoliberalism to be understood as intensifying a pre-existing tradition of socially-embodied practical reasoning, that can be judged inadequate from the standpoint of a rival tradition of rationality.

The much-criticised utilitarianism of neoliberal corporate thinking (Heath and Burden, 2013; Preston and Aslett, 2014), can be traced back to an earlier, liberal form of practical reasoning. Neoliberalism's economic rationality is a pure form of a utilitarianism that subverts human relationships, as Marx saw, into the 'one relationship of usefulness' (Marx in Murray, 1988, p. 73). Utilitarianism obscures the a priori assumptions that set limits on the range of ends that can reasonably be considered. Closely associated with neoliberalism, bureaucratic rationality and utilitarianism are bedfellows in that both require a background set of evaluative commitments about how the world ought to be viewed and which consequently sets the parameters of policy consideration (Maclntyre, 1977, pp. 221-224). Specific neoliberal changes such as increased marketization further narrow the accepted parameters as to what ends can be considered. Bureaucratic rationality therefore flourishes within the neoliberal environment because of the institutionalisation of liberal practical reasoning embodied in the social role of the manager. MacIntyre enables us to see this rationality developing from liberal modernity and embodied in its social structures and roles. Clearly, this rationality fits tightly with neoliberalism which promotes its logic and demands increasingly significant roles for its managerial enactors. Yet a bureaucratic culture that fails to critically question the ends it pursues or the relationship between knowledge and other goods (Heath and Burden, 2013; Preston and Aslett, 2014; Frodeman et al, 2012), is a failure stemming from liberalism itself.

There are several other aspects of MacIntyre's analysis that are important to understanding the neoliberal environment. Just as Mavelli asks: 'How is it possible to account for the resilience of neoliberalism?' (Mavelli, 2017, p. 490), one answer is that liberal modernity's moral impoverishment structurally denies the resources required to challenge it. If bureaucratic rationality 
frames the role of the neoliberal manager, it is the structures of liberal modernity which contribute to the difficulties of challenging neoliberal logic. To understand neoliberalism's durability, we need to understand how liberal modernity constructs its foundations. Extending the analysis of neoliberalism beyond neoliberalism, this suggests liberal modernity itself enables the entrenchment of the neoliberal 'project' of individualising ethics and the systematic promotion of the individual (Olsen, 2008, p. 42; Willis et al, 2008, p. 2). One issue with such literature on neoliberalism is it tends to leave undeveloped this link between liberal modernity and neoliberalism. As discussed earlier, the emphasis on the 'new' is paramount, eclipsing the broader failures of liberal modernity and its role in constructing favourable foundations for neoliberalism.

Maclntyre argues that a central feature of liberal modernity is that it is structured to be unconducive to developing a politics of the common good. Social responsibility and the common good are certainly not the values of neoliberalism, which is often defined by its opposition to such values (Brenner et al, 2010, p. 330; Dean, 2014, pp. 151-152). Yet it is important to recognise that they are also not generally the values of liberalism. Whilst necessary to differentiate, for example, Rawlsian liberalism from neoliberal variants on issues such as social responsibility, a central issue for all variants of liberalism is a failure to acknowledge genuinely common goods, as opposed to individual goods that we might have in common with others. Crucial to neoliberal durability is the modern liberal state, politics and compartmentalization. The state is fundamental in preventing the development of shared practical reasoning necessary to envisage radically different political arrangements (Knight, 2007, p. 170). Along with the market, the state gives concrete expression to the contemporary condition of liberalism, preventing the development of a shared 'rationally justifiable conception of human good' (Maclntyre, 1990, p. 351). The state's decision -making procedures are hierarchically structured and isolated from rational inquiry, making it doubly inadequate in failing to provide the conditions for practical reasoning (Murphy, 2003, pp. 159-160). It is integrated with the market and champions contestable conceptions of liberty and property (Maclntyre, 1999, pp. 209-210). Contemporary politics is 'morally impoverished', making it difficult to see where the moral resources necessary to develop an alternative social system might be obtained (Maclntyre, 2007, p. 262). The state represents the 'good' of the liberal order, of which the overriding purpose is the continuation of the liberal order itself (Maclntyre, 1988, p. 345).

This is one reason why MacIntyre characterises the modern state as 'insidious and destructive' and why his contemporary politics are best understood as trying to find an alternative to the state (MacIntyre, 1995a, p. xxxi; Murphy, 2003, p. 152). For Maclntyre, modern social relationships are structured around 'individualist self-understandings', creating a 'deficient moral reality' for its inhabitants (Pinkard, 2003, p. 189). Any notion of the common good not ultimately reducible to individual goods is rejected by the 'autonomous preference maximizers' that inhabit such an order (MacIntyre, 2016, p. 173). Applying Maclntyre's analysis, the institutions and dominant culture of liberal modernity provides the conditions for neoliberalism to flourish by restricting the development of moral agency and denying access to the institutional arenas necessary to consider and create alternatives (MacIntyre, 2016, p. 108).

Furthering these difficulties, modern politics excludes questions that might articulate rival conceptions of the good, contributing to the 'peculiarly modern' phenomenon of compartmentalization (Maclntyre, 1999a, p. 196). The 'dominant forms of social life militate against the coming into existence' of the 'types of practical rational thought' necessary to asking such 
fundamental questions as 'how is a human life to be valued?' (Maclntyre, 1995a, p. 185). The structures and institutions of liberal society prevent rational debate through which human beings become moral agents. This means that fundamentally Aristotelian questions concerning the nature of the common good and the nature of its inhabitants are incompatible with a compartmentalized society. Compartmentalization is the mutual estrangement of the cultural, political, scientific and economic spheres of human life that denies individuals the ability to become practically rational moral agents (Maclntyre, 1999a, p. 190). There are three parts to compartmentalization. Firstly, each sphere of activity has its own norms and values. Secondly, these spheres are insulated from other spheres - 'in the spiritual zoo; the animals are all in separate cages' (Maclntyre, 1999a, p. 207). Thirdly, and crucially, compartmentalization prevents access to effective practical reasoning that might allow the evaluation of other spheres from an external perspective (Maclntyre, 1999a, p. 199). Politics becomes isolated from considering radical alternatives as it is structurally prevented from going beyond the confines of its own liberal framework. Individuals are unable to acquire the moral and practical resources necessary to question the ends of such societies (Maclntyre, 1992, pp. 111-117).

I have argued that the social structures of liberal modernity are important in constructing favourable conditions for neoliberalism by restricting moral agency through a structurally-reinforced conception of inadequate practical reasoning. By understanding rationalities as social structures, it is possible to conceptualise neoliberal logic as an embodiment of those social structures, and neoliberal managers as enactors of those social roles it assigns, therefore furthering existing analyses of those roles (Ball, 2016; Frodeman et al, 2012; Heath and Burden, 2013). Maclntyre enables a re-examination of neoliberal success and the vulnerability of individuals to neoliberalism's techniques of subjectification. This is in terms of the - essentially liberal - failure of individuals to become practically rational, because of the structurally-reinforced moral impoverishment of the subject. Whilst it is undoubtedly important to examine neoliberalism's ability to renew itself in a seemingly unquestioned way (Peck, 2010; Brenner et al, 2010), it is equally important to recognise the subject's inability to become the kind of practical reasoner that might challenge neoliberalism.

\section{Marx, Foucault and Neoliberal Contradictions}

Foucault's own work, it has been argued, is structured like Hegel's, as a 'trans-historical process' whereby liberal democracy is the 'culmination point of the evolution of history' (Dupont and Pearce, 2001, p. 131). If Foucault did not become an outright supporter of neoliberalism, there remains a close affinity to liberal social democracy (Zamora, 2016, p. 75). This sharply distinguishes Foucault from Maclntyre who has always been highly critical of liberalism (Maclntyre, 1990; 1995; 2007). One consequence of this Foucauldian tendency is shared with numerous critics of neoliberalism - an insufficiently critical attitude towards liberal institutions, leading to an underestimation of the difficulties of envisaging and creating alternatives within its social structures (Giroux, 2011; Harvey, 2007; Beckman et al, 2009). Maclntyre might agree there is a 'certain neo-Hegelianism on the left today' reflected in its tendency to 'counter the nostrums of neoliberalism by extolling the ideal of the state' (Panitch and Gindin, 2011, p. 140). Giroux, for example, argues that a necessary alternative to neoliberalism is a democratic and social state 'expressed in a range of economic, political and cultural institutions' (Giroux, 2011, p. 599). The aim is to develop a de-marketized language of public values, social responsibility and the common good (Giroux, 2011, p. 597). Yet, from a Maclntyrean perspective, this is precisely the kind of role that the modern state is incapable 
of fulfilling. The politics of the common good is alien to liberal modernity, particularly with the intensification, if not transformation, of neoliberal processes.

A further issue here is Foucault's denial of any moral grounds from which to challenge neoliberalism or critique its practices. The 'genealogical narrative' is concerned with disclosing something about the beliefs and activities of groups of individuals, rather than arguing with them (Maclntyre, 1990a, p. 172). Maclntyre views Foucault as he does Nietzsche, precluding the possibility of developing a normative critique of neoliberalism. Projects aiming at rationality, for Foucault, are bound up with a Nietzschean pursuit of power which precludes any genuinely 'moral' activity. Morality is understood as 'resentment, frustration and distortion' (Maclntyre, 1990b, pp. 52-53; 1992, p. 110). If

neoliberalism appealed to Foucault, it was perhaps because it precluded the projection of any moral framework onto the individual (Zamora, 2016, p. 78).

The problem here is that Foucauldian approaches fail to answer the question of 'just why understanding human practices in terms of homo economicus is problematic' (Ongen, 2015, p. 114). Foucault's aim is not the evaluation or comparison of forms of rationality, or the question of the relationship between practices and rationalities. Rather, it is the discovery of what type of rationality is being used (Foucault, 1991; Lemke, 2002). If Foucauldian approaches offer valuable insights, this is at the expense of providing a moral critique. As Gane suggests, to engage with neoliberalism it is necessary to understand its political and epistemological foundations (Gane, 2014, p. 19). If that engagement is to be political, a MacIntyrean analysis contributes to this through developing a critique both moral and political. The Maclntyrean focus on goods, practices and institutions enables a normative critique - and a political alternative - that moves beyond this Foucauldian impasse (Ongen, 2015, p. 111). If neoliberalism aspires to construct responsible subjects whose moral quality is rooted in their rational cost-benefit assessment of practices (Lemke, 2002), there needs to be some basis from which this understanding of morality and practices can be challenged. It is MacIntyre's Aristotelian project that aims to provide such a basis. MacIntyre views the discarding of the Aristotelian teleological project as removing the possibility of justifying morality not only in terms of what is, but of what ought to be (Knight, 1998, p. 8). Ultimately, it is only a radically different moral scheme of ends and common goods that might move beyond the Nietzschean antimorality that Foucault develops, whilst simultaneously giving expression to political alternatives.

Marxism, too, is open to similar charges of moral and political deficiency, if for different reasons. Maclntyre suggests Marxism fails to ask the questions of how one becomes the type of person, or what type of person one needs to become, to actively desire alternative social arrangements (MacIntyre, 2016, p. 282). These questions are inherently Aristotelian, concerning the nature and meaning of goods and the good. Aristotelianism recognises that rationally adequate practical and moral concepts require a specific social order - or social practice - in which they can be embodied (Maclntyre, 1992, p. 111). Practices are constituted by activity through which individuals can achieve something universally worthwhile through cooperation with other practitioners (Maclntyre, 1994). Despite Marx's recognition of this Aristotelianism in his Theses on Feuerbach, he came to associate such practices with already-defeated forms of life and abandoned these philosophical insights for the sake of future political struggle (Maclntyre, 1994). Marxists carried forward this revolutionary commitment and, consequently, the inability to ask questions as to how we should live and the nature of the good. Marxism fails to ask questions about the meaning and content of human flourishing beyond an essentially unquestioned conception of socialism, therefore failing to 
understand the Aristotelian structure of practices through which such questions may be asked and answered.

Marxism, according to this view, fails to develop a political alternative to neoliberalism partially due to its philosophical inattention to social practices. Yet it is important not to build a straw-man argument against Marxism. Much Marxist literature on neoliberalism recognises not only the nuances of neoliberalism, but the potentialities contained within localised forms of resistance beyond what Harvey calls the 'utopian Marxist fantasy' of some dogmatic version of class struggle (Harvey, 2007, p. 202). Dunn, for example, suggests that whilst labour must act globally, capital is vulnerable to localised struggles which can complement wider resistance (Dunn, 2016, pp. 320-321). Accordingly, one need not preclude the view that localised resistance can contribute to globalised forms of struggle. Yet there are two areas in which Maclntyre (himself a former Marxist) arguably goes beyond Marxism. Firstly, his analysis of liberal modernity helps to explain the difficulties of resisting neoliberalism in a way that precludes any problematic recourse to the state. Secondly, his Aristotelianism provides a clearer analysis of the structure of social practices. MacIntyre's view of the modern state challenges Marxism as he argues that those who aim at the conquest of state power are themselves conquered by it. Marxism becomes an instrument 'of one of the several versions of modern capitalism' (Maclntyre, 1995, p. xv), precluding wider forms of globalised resistance and the overthrow of the system that Marxists envisage.

However, even accepting the possibility of wider resistance, it remains crucial to understand how social practices might contribute to this. Practices are both moral and political - the former because they act as arenas where individuals develop their own good and the latter because they are directed towards the goods of communities. Maclntyre characterises practices as inherently Aristotelian - they have internal goods and rationalities (Knight, 2008, pp. 327-328). Aristotelianism names a form of activity developed from within social practices that might question and resist neoliberal rationality, providing a moral and political aspect largely absent from Marxist and Foucauldian perspectives.

There are two interrelated areas that need to be understood if we are to further highlight a Maclntyrean contribution. The first is how a Maclntyrean analysis links with the contradictory nature of neoliberalism and, secondly, the potential areas where resistance develops. Significantly, neoliberalism is more accurately understood as a 'mobile technology' rather than the 'economic tsunami' it is often made out to be (Ong, 2007, p. 3). Neoliberalism is not monolithic, it is a historically-variant process, characterised by its uneven and contradictory nature (Barnett, 2005; Brenner et al, 2010; Gamble, 2006; Larner, 2000; Ong, 2007; Peck, 2010; Wacquant, 2009). There is an emerging tendency to challenge the reification of neoliberalism into an all-encompassing phenomenon, manifested everywhere and in everything (Gamble. 2006. P. 34). Wacquant notes the combination of circumstance and trial and error which refutes any hyper-deterministic understanding of the neoliberal state (Wacquant, 2009, pp. 312-313). Neoliberalism is inherently contradictory as its goal of pristine market rule is fundamentally unachievable; it can fail, even if it has tended to 'fail forward' and re-strengthen itself (Peck, 2010). Consequently, neoliberalism's contradictory nature fosters conflict, creating possibilities for localised politics, and the 'profoundly pessimistic' assertion that only the 'total overthrow' of the system constitutes meaningful resistance can be challenged (Gamble, 2006, pp. 34-35). 
These analyses of neoliberalism seemingly create an opportunity for convergence with Maclntyre's politics of local community. Nevertheless, it is important to recognise this avenue of localised resistance has no automatic claim to a politics of the common good. Neoliberalism can embed itself in local communities and re-appropriate political projects to make these suitable for neoliberal interests (Clarke, 2008, pp. 39-140). Dagnino identifies the 'perverse confluence' between social movements and neoliberal politics (Dagnino in Clarke, 2008, p. 139), potentially leaving the politics of local community vulnerable to both state-led and localised neoliberal strategies. This is particularly important when we remember the Foucauldian view of the state as one instrument of power amongst broader strategies of governing. Just as the state cannot provide a political framework for achieving common goods, those regimes of subjectification associated with governmentality (Mavelli, 2017, p. 491), create equally profound difficulties.

The problem is not only neoliberalism's political strategies, or the nature of the state, it is the question of how to resist those subject-transformational processes crystalized in Foucault's Homo Economicus. If we recognise both neoliberalism's ability to embed itself in local communities and its creation of a favourable subject in its own image, the difficulties of resistance are amplified.

Neoliberalism can modify its central values to embed itself locally, legitimising the market economy through appealing to values representative of specific local communities (Olsen, 2008, p. 57). This points towards neoliberalism's processes of articulation and assemblage; the former involving the articulation of things into 'neoliberalism's repertoire', the latter, the transference of elements of that repertoire into local assemblages to 'remake' particular places (Clarke, 2008, p. 144). Neoliberalism is adept, if not at defeating its enemies then at converting them to its own ideas (Zamora, 2016, p. 80).

\section{Practices and Communities of Resistance}

Maclntyre also recognises that local communities are open to corruption and deformation (Maclntyre, 1999b, p. 142), yet more must be said about the nature and form of his politics that might resist these processes. After elaborating more clearly on the crucial role of social practices, it is incumbent on my argument to demonstrate concrete application. Put straightforwardly, the political significance of MacIntyre's adaptation of the Aristotelian tradition is that it fosters the virtues - qualities of mind and character - which are necessary to resist corruption, question neoliberal economic rationality, and act as a bulwark against the institutionalised pursuit of external goods (Maclntyre, 1992, p. 122). Moral agency only flourishes within a specifically Aristotelian social and political order or, on Maclntyre's terms, within practice-based communities (Maclntyre, 1992, p. $111 ; 1995$, p. 155). Social practices foster an alternative framework of Aristotelian rationality to that of the neoliberal subject's economic rationality which, Foucault argues, atomistically extends to every social actor (Foucault, 2008, p. 9; p. 223; p. 282). This suggests a process of 'embedded neoliberalism' that constructs a specific image of the favourable neoliberal subject that coheres with the rolling out of neoliberal governmentality (Joseph, 2013; Walker and Cooper, 2011). The successful promotion of neoliberal logic is therefore partially dependent on the fostering of a specific self-image of the individual, rooted within liberalism's political and economic framework, extending to something like Foucault's Homo Economicus.

Yet, albeit it differently, the subject-transformative quality of social practices is as important to Aristotelianism as it is to neoliberalism's homo economicus. Aristotelian politics normatively 
challenge the model of the neoliberal subject and provides the political arena for resisting the extension of this model. If neoliberalism constructs morality in economic terms, and Homo Economicus reflects this in its unquestioning characterisation of practices as cost-benefit exercises (Lemke, 2002), Aristotelianism provides an alternative moral and political framework (Ongen, 2015). Aristotelian politics aims to create alternative institutions embodying rationally justifiable conceptions of the common good through 'institutionalized forms of practical reasoning' (Maclntyre, 1990 , p. $351 ; 1992$, p. 122). Aristotelianism is the cooperative, rational determination of both ends and means within social practices (Knight, 2007, p. 159), therefore making a double rejection of neoliberal practical reasoning. Maclntyre suggests that the ends of a practice involve objective activity which is 'characterizable antecedently and independently of any characterization of the desires' of those individuals engaged in it (Macintyre, 1994, p. 225). Practices can therefore be transformative of desire and can provide an arena of resistance against neoliberal rationality and a conflicting image of the good.

Practices are the core constituent of Maclntyre's moral theory and foundational to a three-stage process of the development of virtue (Maclntyre, 2007, p. 186). The second stage, an account of a human life, presupposes the third, a moral tradition. Yet both are presupposed by practices. It is from within practices that virtuous human life and moral traditions develop. Within practices, people develop moral agency from which they begin to question the contemporary order. Maclntyre defines a practice as:

any coherent and complex form of socially established cooperative human activity through which goods internal to that form of activity are realized in the course of trying to achieve those standards of excellence which are appropriate to, and partially definitive of, that form of activity, with the result that human powers to achieve excellence, and human conceptions of the ends and goods involved, are systematically extended (Maclntyre, 2007, p. 187).

Maclntyre gives examples of practices - Chess, physics and medicine are practices, whilst chess clubs, laboratories, universities and hospitals are institutions (Maclntyre, 2007, p. 194). The defining feature of a practice is that it possesses internal goods - goods common to both the participants and the practice. Internal goods or goods of excellence are internal for two reasons. Firstly, in the sense that such goods can only be specified in relation to a specific form of practice (Maclntyre, 2007, p. 188); secondly, they can only be identified and obtained by those participating in practices. A defining characteristic of internal goods is that 'their achievement is a good for the whole community who participate in that practice' (MacIntyre, 2007, pp. 190-191). Internal goods cannot be reduced to the pursuit of external goods, so the pursuit of such goods within well-ordered practices cannot be for instrumental purposes.

The transformative quality of Aristotelian social practices is important as it allows an alternate conception of practical reasoning to flourish through which practitioners might distinguish between good and bad desires, or between genuine goods of community and those incursions of neoliberal rationality that masquerade as goods of community. On a localised level, neoliberalism manifests itself through the discourse of putting local people 'in the driving seat'; yet the reality of such 'bottom-up' approaches is that these are an illusionary autonomy (Joseph, 2013, p. 48; p. 49), ultimately serving as a pretext for strengthening neoliberal interests. Yet the way that Maclntyre now conceives of virtues as being properties not of the practice but of practitioners - practices serve 
as 'schools' of the virtues - is important to understanding how communities begin to differentiate between conflicting goods. As individuals pursue goods internal to practices, they become moral agents through discovering goods greater than those of their 'untutored' desires (Knight, 2007, pp. 151-154), therefore embodying a form of practical rationality opposed to the neoliberal image of practices and practitioners.

This allows practices to be understood as sites of contestation, as social 'milieus' against the impingement of localised neoliberalism, providing virtuous resistance to its degenerative moral and political influence. The possession of the virtues ensures that individuals inhabit two conflicting moral systems - that of the neoliberal order and that of those practices which put that order into question (Maclntyre, 1999a, p. 193). A social practice is in good order when it develops the virtues amongst its practitioners, the possession of which are necessary to identify, question and resist neoliberal goods and pursue the genuine goods of community. This suggests a localised form of neoliberalism that might modify its central values to embed itself in communities, can potentially be resisted by conflicting forms of practical rationality developed within social practices by moral agents (Maclntyre, 1992, p. 122).

It is important not to ignore the charge that Maclntyre's politics are exclusionary or utopian. Maclntyre is often criticised for his refusal to engage with the state and the exclusionary implications of his politics. His understanding of politics excludes the view that the modern state is compatible with a politics of the common good. Yet whilst Maclntyre strives for politics far removed from the state, he recognises the necessity of interaction with it. He cites the Americans with Disabilities Act as an example of positive social policy developing from the relationship between communal movements and the state. Indeed, the state is sometimes the only means for removing obstacles to 'human goals' (Maclntyre, 1999b, p. 133; 2000). What is needed is a 'double attitude' to the state that recognises both its inability to embody common goods and its provision of valuable resources (Maclntyre, 1999b, p. 133). It is vital to recognise that the state is both an ineliminable institution and that it tends to pursue goods external to practices. The hope, in this context, is to make practices and workplaces scenes of resistance (Maclntyre, 2006), potentially subordinating the institutional pursuit of money and power to those goods internal to practices (Knight, 2007, p. 183).

Contrary to the exclusionary or utopian criticisms, a key strength of Maclntyre's analysis is that it can frame resistance in a variety of forms, from specific practices of cooperative fishing crews (Maclntyre, 2016), to much wider communities of resistance. It is therefore important to sketch a model of the relevance of Maclntyrean thought within concrete political settings that might fit with this notion of communities of resistance. The way this can be done is by connecting specific practices, for instance the - distinctly non-political sounding - practice of the making and sustaining of family life, with Maclntyre's wider notion of politics as the making and sustaining of local community - itself a form of practice. It is the dependence of the goods of specific practices such as these on wider political and economic issues which potentially provides the bridge between the practices of the family and those practices of the wider community (MacIntyre, 2016, p. 176). If family life is a practice characterised by the identification and achievement of common goods, those goods embodied are inextricably linked to wider, societal issues - employment, security, stability and such. In the pursuit of those goods it becomes, or might become, incumbent on practitioners to act to defend those goods if societal issues threaten the ability of those practices to flourish. 
A concern for common goods entails a strong political commitment, expressed through a range of local organizations concerned with furthering those goods. Wider, more explicitly political, community movements can be viewed as forms of social practices in that they embody conceptions of common goods, of human flourishing, in their aim of making and sustaining community life within the context of a range of interdependent social practices of work, family and community. As specific practices engage with the wider social, economic and political framework in order to flourish, new, related practices are formed that reflect these engagements with the social order. I am thinking here particularly of the Black Lives Matters movement (BLM).

Those practices and communities foundational to BLM have long-resisted oppression, state violence, and colonialism (Lebron, 2017). And this well before neoliberalism was conceived. One cannot primarily equate structural racism with neoliberalism, nor suggest that by resisting the latter the former will disappear. Structural racism is nevertheless shaped by neoliberalism as seen in the nature and role of the Criminal Justice system and institutions such as the police (Wacquant, 2009). And without falsely attributing to BLM a universal opposition to neoliberalism, it is relevant that black activists and scholars have identified the inadequacies of both liberal democracy and neoliberalism (Hooker, 2016; Ransby, 2018). Similarly, despite Maclntyre having little to say on firstly racism and secondly neoliberalism, it is the conjoining of inadequate liberal reasoning and institutions with neoliberalism which are relevant to understanding the latter, and which provide an opportunity to engage with and learn from those practices that challenge the former. This provides a point of contact between MacIntyre's neo-Aristotelian critique of liberal modernity, its relationship to neoliberalism, and those practices and communities that exemplify resistance within a neoliberal context.

It is of primary importance here to recognise that BLM began as a response to the everyday lived experiences of structural racism within the black community. The continuing threat of racism to those communities cannot be adequately theorised from an external position such as that of white academia. It is only practitioners themselves that develop goods internal to practice, and it is only people of colour whose communities are specifically threatened in such a way. Yet this does not prevent us learning from these movements - as to how practical reasoning develops and what the points of contact might be between BLM and Aristotelianism. Not insignificantly, it is necessary to note a possible tension between Aristotle, as a believer in natural slavery, and any kind of neoAristotelian engagement with movements such as BLM. My own view here is shared by Maclntyre, that a thorough rejection of those abhorrent, factual elements of Aristotle's own beliefs, does not invalidate the overall moral conceptual scheme on which contemporary Aristotelianism is based.

There are, then, three such points of contact between BLM and Maclntyre's politics of local community. The first links with Maclntyre's critique of liberalism and the state and the nature and setting of such resistance. Juliet Hooker places BLM in the context of the profound failures of liberal democracy to address racial justice, developing a powerful critique of the limitations of liberalism in addressing structural disparities. She suggests that racial justice might only be achieved through a 'politics of active resistance' which itself cannot be easily theorised from 'within the bounds' of liberal democracy (Hooker, 2016, p. 464). The implication, shared with a MacIntyrean perspective, is that resistance which can challenge the social order needs to be distinct from state and system, and theorised from a radical perspective that goes beyond the limitations of that same system. Even as black communities have been marginalised and excluded from the political process, their ability to 
build grassroots power within such communities (Black Lives Matter, 2020), and in many ways against the state, provides a conception of political activity that frees itself from the limitations of liberal democracy and provides a concrete platform for addressing its failures. Indeed, one way to conceptualise such movements would be that they might further what Maclntyre agrees are important liberal values - freedom, social justice and resistance to oppression. One key problem with liberalism, for MacIntyre, is that it ultimately betrays its ideals by being unable to deliver these in practice, therefore alternative politics might potentially succeed where liberalism fails.

Secondly, I think MacIntyrean thought is relevant to what Hooker calls the development of 'contingent solidarities' that result from structural conditions (Hooker, 2009, p. 37). It is the experiences that people have of the social order that provide an opportunity for social change through their involvement in a variety of projects (Maclntyre 2011, p. 10). As people question their own experiences and become involved in collective decision-making processes at a localised level or for a specific project, they might ask wider, more fundamental Aristotelian questions about the nature of particular goods - education, childhood, work - and how the system conceives of these goods. If one conceives of BLM as a grassroots community movement, it is possible to see an Aristotelian structure to its reasoning, in that experiences of racism are contextualised within a critique of the neoliberal systems in place - economics, housing, food, prisons, the recognition of which has led to a wider criticism of the social order itself (Clayton, 2018), and a questioning of the conception of good and goods that it embodies. Whilst a practice is initially concerned with internal goods, the pursuit of these can lead to fundamental political and moral questions about human goods (Maclntyre, 2011). A practice therefore has a dual role of providing internal, impersonal standards of excellence as well as 'an ethically educative goal and good' (Knight, 2011, p. 311), structured like the lived experiences of everyday people. These lived experiences potentially lead to a questioning of the nature and meaning of the human good in different contexts. This, in turn, relates to the notion of interdependent, contingent practices and solidarities, that might come together to protect conceptions of the good that conflict with the social order, as was evident when trade unions and BLM cooperated in St Louis and New York (Larson, 2016, p. 41). The hope is that within the context of a variety of practices, practitioners' initially 'untutored' desires become 'informed', and that the former are subordinated to the alternative practical reasoning that is embodied in the latter (Maclntyre, 2016, p. 177, p. 176; Knight, 2008, p. 322).

This leads on to the third, related point - that the politics of local community need not remain confined to the local. Whilst BLM began through an online community, it manifested itself in localised protests that became joined up in a way that impacted the social order as a whole. BLM provides a concrete case study of how communities of resistance function and can have a wider political impact. This can be partially interpreted through an Aristotelian understanding of social practices, common goods and rationality. Hooker argues that one of the achievements of BLM's protests is that they have rendered 'wilful white ignorance' about the wider context of black dehumanization more difficult to sustain (Hooker, 2016, p. 463). This illuminates the connection between police violence and other racialised societal risks that emerge from the same set of social and political structures (Miller, 2014). It is therefore crucial to any Maclntyrean understanding of resistance that it characterises social practices beyond either the confines of highly specific practices or very particular social settings. BLM is exemplary in illustrating how this might happen.

Fundamental to this is an understanding of communities of resistance that embody oppositional conceptions of the common good that can be joined up with others to have a profound societal 
impact. Such new forms of community organisation as BLM can perhaps be viewed as forms of social practices, often conflicting with the neoliberal state, and going beyond more isolated examples which Maclntyre refers to. None of this suggests that all social protest movements come to resemble Aristotelian social practices - such activities are open to the misdirection of desire, the degenerative influence of state and market, and so on. Yet it perhaps shows there is a theoretical and practical relevance to Aristotelianism. The way that individuals engage in cooperative activity to develop alternate conceptions of the good to that of the social order, and in the process transform themselves and society, is arguably testament to that.

Governmentality, Ideology, and Marxist interpretations provide valuable resources for understanding neoliberalism. Yet these need to be accompanied with an understanding of how liberal modernity institutionalises an inadequate form of practical reasoning, making its logic difficult to break from. Maclntyre provides a framework through which neoliberal economic rationality can be deemed morally impoverished. Challenging the Foucauldian rejection of moral practice, leftist calls for state-led institutional reform, and Marxian understandings of revolutionary practice, revolutionary Aristotelianism characterises a form of resistance to neoliberalism developed from within social practices. As individuals engage in practices, they become the kind of people who might challenge neoliberalism. There are a multitude of practices in which individuals are involved - in work, leisure, family life and communities. Through these, individuals' question dominant ideological views and their own social roles by reflecting on and engaging in wider forms of activity that are interdependent with other social practices. Moral agency develops within these practices, where an alternative moral system might develop that conflicts with the contemporary social order (MacIntyre, 1999a, p. 193; 2016). Whilst unrealistic to advocate a politics of complete withdrawal from the state, it remains crucial to the politics of resistance that it is not co-opted by the individualising logic and means-end reasoning of such institutions. One fruitful way to ensure this is through the promotion and defence of practices and social movements that embody internal and common goods, and which contain the potential to challenge neoliberalism in theory and practice. 


\section{References}

Ball, S.J. (2016) Neoliberal Education? Confronting the Slouching Beast. Policy Futures in Education 14(8): 1046-1059.

Ball, S.J. and Olmedo, A. (2013) Care of the Self, Resistance and Subjectivity under Neoliberal Governmentalities. Critical Studies in Education 54(1): 85-96.

Barnett, C. (2005) The consolations of 'neoliberalism'. Geoforum 36: 7-12.

Beabout, G. (2013) The Character of the Manager: From Office Executive to Wise Steward. New York: Palgrave Macmillan.

Beckman, A., Cooper, C. and Hill, D. (2009) Neoliberalization and Managerialization of 'Education' in England and Wales - A Case for Reconstructing Education. Journal for Critical Education Policy Studies 7: 311-345.

Black Lives Matter. (2020) 6 Years Strong. https://blacklivesmatter.com/six-years-strong/.

Brenner, N. Peck, J. and Theodore, N. (2010) After Neoliberalization? Globalizations 7(3): 327-345.

Clarke, J. (2008) Living with/in and without neo-liberalism. Focaal 51: 135-147.

Clayton, M.D. (2018) Black Lives Matter and the Civil Rights Movement: A Comparative Analysis of Two Social Movements in the United States. Journal of Black Studies 49(5): 448-480.

Davidson, N. (2013) The Neoliberal Era in Britain: Historical Developments and Current Perspectives. International Socialism 139: 171-223.

Dean, M. (2014) Rethinking Neoliberalism. Journal of Sociology 50(2): 150-163.

Dumenil, G. and Levy, D. (2005) The Neoliberal (Counter-)Revolution. In: Saad-Filho, A. and Johnston, D. (eds.) Neoliberalism: A Critical Reader. London: Pluto Press, pp. 9-19.

Dunn, B. (2009) Global Political Economy: A Marxist Critique. London: Pluto Press.

Dupont, D. and Pearce, F. (2001) Foucault Contra Foucault: Rereading the 'Governmentality' Papers. Theoretical Criminology 5(2): 123-158.

Foucault, M. (1991) Questions of Method. In: Burchell, G., Gordon, C. and Miller, P. (eds.) The Foucault Effect: Studies in Governmentality. Hemel Hempstead: Harvester Wheatsheaf, pp. 73-86.

Foucault, M. (2008) The Birth of Biopolitics. New York: Palgrave MacMillan.

Frodeman, R., Briggle, A. and Holbrook, J.B. (2012) Philosophy in the age of Neoliberalism. Social Epistemology 26(3-4): 311-330.

Gamble, A. (2006) Two Faces of Neo-Liberalism. In Robison, R. (ed.) The Neo-Liberal Revolution: Forging the Market State. Hampshire: Palgrave MacMillan, pp. 20-35.

Gane, N. (2014) The Emergence of Neoliberalism: Thinking Through and Beyond Michel Foucault's Lectures on Biopolitics. Theory, Culture \& Society 31(4): 3-27. 
Giroux, H. (2011) Neoliberalism and the Death of the Social State: Remembering Walter Benjamin's Angel of History. Social Identities 17(4): 587-601.

Harvey, D. (2007) A Brief History of Neoliberalism. Oxford: Oxford University Press.

Heath, M. and Burdon, P.D. (2013) Academic Resistance to the Neoliberal University. Legal Education Review 23: 379-402.

Hindess, B. (1997) Discourses of Power: From Hobbes to Foucault. Oxford: Blackwell.

Hooker, J. (2009) Race and the Politics of Solidarity. Oxford: Oxford University Press.

Hooker, J. (2016) Black Lives Matter and the Paradoxes of U.S. Black Politics: From Democratic Sacrifice to Democratic Repair. Political Theory 44(4): 448 -469.

Joseph, J. (2013) Resilience as embedded neoliberalism: a governmentality approach. Resilience 1(1): 38-52.

Knight, K. (1998) Editor's Introduction. In: Knight, K. (ed.) The MacIntyre Reader. Cambridge: Polity Press, pp. 1-30.

Knight, K. (2007) Aristotelian Philosophy: Ethics and Politics from Aristotle to Macintyre. Cambridge: Polity.

Knight, K. (2008) Practices: The Aristotelian Concept. Analyse \& Kritik 30(2): 317-329.

Knight, K. (2011) What's the good of post-analytic philosophy? History of European Ideas 37: 304314.

Larner, W. (2000) Policy, Ideology, Governmentality. Studies in Political Economy 63: 5-25.

Larson, E.D. (2016) Black Lives Matter and Bridge Building: Labor Education for a "New Jim Crow" Era. Labor Studies Journal 41(1): 36-66.

Lebron, C.J. (2017) The Making of Black Lives Matter. Oxford: Oxford University Press.

Lemke, T. (2002) Foucault, Governmentality, and Critique. Rethinking Marxism, 14(3): 49-64.

Lutz, C.S. (2004) Tradition in the Ethics of Alasdair MacIntyre. Oxford: Lexington Books.

Maclntyre, A. (1977) Utilitarianism and Cost-Benefit Analysis: An Essay on the Relevance of Moral Philosophy to Bureaucratic Theory. In: Sayre, K. (ed.) Values in the Electric Power Industry. Notre Dame and London: University of Notre Dame Press, pp. 217-237.

Maclntyre, A. (1977a) Epistemological Crises, Dramatic Narrative and the Philosophy of Science. The Monist 60(4): 453-472.

MacIntyre, A. (1987) Practical Rationalities as Forms of Social Structure. In: Knight, K. (ed.) The MacIntyre Reader. Cambridge: Polity Press, pp. 120-135.

Maclntyre, A. (1988) Whose Justice? Which Rationality? Notre Dame: University of Notre Dame Press. 
Maclntyre, A. (1990) The Privatization of the Good. The Review of Politics 52(3): 344-377.

MacIntyre, A. (1990a) First Principles, Final Ends, and Contemporary Philosophical Issues. In: Maclntyre, A. (2006a) The Tasks of Philosophy: Selected Essays (Vol. 1). Cambridge: Cambridge University Press, pp. 143-178.

Maclntyre, A. (1990b) Three Rival Versions of Moral Enquiry. Indiana: University of Notre Dame Press.

Maclntyre, A. (1991) A Short History of Ethics. London: Routledge.

Maclntyre, A. (1992) Moral Philosophy and Contemporary Social Practice: What Holds Them Apart? In: MacIntyre. A. (2006a) The Tasks of Philosophy: Selected Essays (Vol. 1). Cambridge: Cambridge University Press, pp. 104-124.

Maclntyre, A. (1994) The Theses on Feuerbach: A Road Not Taken. In: Knight, K. (1998) (ed.) The MacIntyre Reader. Cambridge: Polity, pp. 223-234.

MacIntyre, A. (1995) Introduction: Three perspectives on Marxism: 1953, 1968, 1995. In: MacIntyre, A. (1995) Marxism and Christianity (2nd ed.) London: Duckworth, pp. v-xxxi.

MacIntyre, A. (1995a) Some Enlightenment Projects Reconsidered. In: MacIntyre, A. (2006) Ethics and Politics: Selected Essays (Vol. 2). Cambridge: Cambridge University Press, pp. 172-185.

Maclntyre, A. (1999) Toleration and the Goods of Conflict. In: Maclntyre, A. (2006) Ethics and Politics: Selected Essays (Vol. 2). Cambridge: Cambridge University Press, pp. 205-223.

MacIntyre, A. (1999a). Social Structures and Their Threat to Moral Agency. In: Maclntyre, A. (2006) Ethics and Politics: Selected Essays (Vol. 2). Cambridge: Cambridge University Press, pp. 186-204.

Maclntyre, A. (1999b) Dependent Rational Animals. Illinois: Carus Publishing Company.

Maclntyre, A. (2000) The Need for a Standard of Care. In: Francis, L.P. and Silvers, A. (2000) (eds.) Americans With Disabilities: Exploring Implications of the Law for Individuals and Institutions. London: Routledge, pp. 81-86.

MacIntyre, A. (2006) Outside Ethics. Notre Dame Philosophical Reviews. Available from http://ndpr.nd.edu/review.cfm?id=5922

Maclntyre, A. (2007) After Virtue (3rd ed.). Notre Dame: University of Notre Dame Press.

Maclntyre, A. (2011) How Aristotelianism can become Revolutionary. In: Blackledge, P. and Knight, K. (eds.) Virtue and Politics: Alasdair MacIntyre's Revolutionary Aristotelianism. Indiana: University of Notre Dame Press, pp. 8-12.

MacIntyre, A. (2016) Ethics in the Conflicts of Modernity. Cambridge: Cambridge University Press.

Marx, K. (1969) Theses on Feuerbach. In: Marx/Engels Selected Works (Vol. 1). Moscow: Progress Publishers, pp. 13-15. 
Mavelli, L. (2017) Governing the Resilience of Neoliberalism through Biopolitics. European Journal of International Relations 23(3): 489-512.

Miller, L.L. (2014) Racialized State Failure and the Violent Death of Michael Brown. Theory \& Event $17(3)$.

Murphy, M.C. (2003) MacIntyre's Political Philosophy. In: Murphy, M.C. (ed.) Alasdair MacIntyre: Contemporary Philosophy in Focus. Cambridge: Cambridge University Press, pp. 152-175.

Murray, P. (1988) Marx's Theory of Scientific Knowledge. New Jersey: Humanities Press.

North, P. (2008) Voices from the Trueque: Barter Networks and Resistance to Neoliberalism in Argentina. In: Smith, A., Stenning, A. and Willis, K. (eds.) Social Justice and Neoliberalism: Global Perspectives. London and New York: Zed Books, pp. 16-38.

Olsen, E. (2008) Confounding Neoliberalism: Priests, Privatization and Social Justice in the Peruvian Andes. In: Smith, A., Stenning, A. and Willis, K. (eds.) Social Justice and Neoliberalism: Global Perspectives. London and New York: Zed Books, pp. 39-60.

Olssen, M. and Peters, M. A. (2005) Neoliberalism, Higher Education and the Knowledge Economy: From the Free Market to Knowledge Capitalism. Journal of Education Policy 20(3): 313-345.

Ong, A. (2007) Neoliberalism as a Mobile Technology. Transactions of the Institute of British Geographers 32(1): 3-8.

Ongen, M. (2015) Reappraising Neoliberalism: HomoEconomicus, Practitioners and Practices. In: Bielskis, A. and Knight, K. (eds.) Virtue and Economy: Essays on Morality and Markets. New York: Routledge, pp. 109-134.

Panitch, L. and Gindin, S. (2005) Euro-Capitalism and American Empire. In: Coates, D. (ed.) Varieties of Capitalism, Varieties of Approaches. Hampshire: Palgrave MacMillan, pp. 139-160.

Peck, J. (2010) Zombie Neoliberalism and the Ambidextrous State. Theoretical Criminology 14(1): 104-110.

Pinkard, T. (2003) MacIntyre's Critique of Modernity. In: Murphy, M. C. (ed.) Alasdair Maclntyre: Contemporary Philosophy in Focus. Cambridge: Cambridge University Press, pp. 176-200.

Preston, S. and Aslett, J. (2014) Resisting Neoliberalism from within the Academy: Subversion through an Activist Pedagogy. Social Work Education 33(4): 502-518.

Ransby, B. (2018) Making All Black Lives Matter: Reimagining Freedom in the Twenty-First Century. Oakland: University of California Press.

Venugopal, R. (2015) Neoliberalism as Concept. Economy and Society 44(2): 165-187.

Wacquant, L. (2009) Punishing the Poor: The Neoliberal Government of Social Insecurity. Durham: Duke University Press. 
Walker, J. and Cooper, M. (2011) Genealogies of Resilience: From Systems Ecology to the Political Economy of Crisis Adaptation. Security Dialogue 42(2): 143-160.

Willis. K., Smith, A. and Stenning, A. (2008) Introduction: Social Justice and Neoliberalism. In: Smith, A., Stenning, A. and Willis, K. (eds.) Social Justice and Neoliberalism: Global Perspectives. London and New York: Zed Books, pp. 1-15.

Zamora, D. (2016) Foucault, the Excluded, and the Neoliberal Erosion of the State. In: Zamora, D. and Behrent, C. (eds) Foucault and Neoliberalism. Cambridge: Polity Press, pp. 63-84. 